\title{
Nitrous Oxide Decomposition over Alkali-Promoted Magnesium Cobaltite Catalysts
}

\author{
Bahaa M. ABU-ZIED* \\ Chemistry Department, Faculty of Science, Assiut University, 71516 Assiut, Egypt
}

\begin{abstract}
The direct decomposition of $\mathrm{N}_{2} \mathrm{O}$ was investigated over a series of magnesium cobaltite catalysts, $\mathrm{Mg}_{x} \mathrm{Co}_{1-x} \mathrm{Co}_{2} \mathrm{O}_{4}(0.0 \leq x \leq 1.0)$, which were prepared by the thermal decomposition of stoichiometric amounts of magnesium hydroxide and cobalt acetate. The thermal genesis of the different catalysts from their precursors was explored using thermogravimetric analysis, differential thermal analysis, and X-ray diffraction. Texture analysis was carried out using $\mathrm{N}_{2}$ adsorption at $-196{ }^{\circ} \mathrm{C}$. We found that all the catalysts that were calcined at 500 ${ }^{\circ} \mathrm{C}$ have a spinel structure. $\mathrm{N}_{2} \mathrm{O}$ decomposition activity was found to increase with an increase in the spinel structure's magnesium content. The influence of alkali cation promoters ( $\mathrm{Li}, \mathrm{Na}, \mathrm{K}$, and $\mathrm{Cs}$ ) on the activity of the most active catalyst in the $\mathrm{Mg}_{x} \mathrm{Co}_{1-x} \mathrm{Co}_{2} \mathrm{O}_{4} \mathrm{series}$, i.e. $\mathrm{MgCo}_{2} \mathrm{O}_{4}$, was also investigated. The sequence of the promotional effect was found to be: un-promoted $<\mathrm{Li}<\mathrm{Na}<\mathrm{Cs}<\mathrm{K}$-promoted catalyst. The reason for the increase in activity for the added alkali cations was electronic in nature. Additionally, the dependence of the activity on the $\mathrm{K} / \mathrm{Co}$ ratio was also determined. The highest activity was obtained for the catalyst with a $\mathrm{K} / \mathrm{Co}$ ratio of 0.05 . A continuous decrease in activity was obtained for higher $\mathrm{K} / \mathrm{Co}$ ratios. This decrease in activity was attributed to the elimination of mesoporosity in the catalysts with $\mathrm{K} /$ Co ratios $>0.05$, based on $\mathrm{N}_{2}$ adsorption and scanning electron microscopy results.
\end{abstract}

Key words: nitrous oxide; cobalt oxide; magnesium cobaltite; spinel; alkali promotion

CLC number: O643 Document code: A

Nitrous oxide is a dangerous environmental pollutant because of its high greenhouse potential and its ozone-depleting property [1]. The Kyoto Protocol of the United Nations Convention on Climate Change (December 1997) cites $\mathrm{N}_{2} \mathrm{O}$ as a second non- $\mathrm{CO}_{2}$ greenhouse gas. $\mathrm{N}_{2} \mathrm{O}$ has an atmospheric lifetime of more than a century and its global warming potential (GWP) is 310 times higher than that of $\mathrm{CO}_{2}$ [2]. $\mathrm{N}_{2} \mathrm{O}$ emissions come from natural sources and human activity such as the production of chemicals (adipic acid, nitric acid, acrylonitrile, nylon, caprolactame), combustion processes, road vehicles, and medical exhausts etc. A catalytic process seems to be an attractive way to solve this environmental problem. $\mathrm{N}_{2} \mathrm{O}$ decomposition into nitrogen and oxygen has been thoroughly studied over various catalysts [3-9].

Metal cobaltites belong to a class of complex oxides referred to as spinels and they have a composition of $\mathrm{AB}_{2} \mathrm{O}_{4}$ where the $\mathrm{A}$ ions are generally bivalent metal ions that occupy tetrahedral sites and B ions are trivalent ions that occupy octahedral sites. Cobaltites have attracted much attention from chemists because of their application in low cost fuel cell electrodes [10] and as anodes for Li-ion batteries [11]. As catalysts, they have well-established catalytic properties in many reactions such as ammonia oxidation [12], carbon monoxide oxidation [13,14], methanol decom- position [15], benzene oxidation [16], conversion of synthesis gas to light olefins [17], total oxidation of propane [18], methane combustion [19], and hydrogen peroxide decomposition [20]. The activity of the cobalt containing spinels towards the direct decomposition of nitrous oxide was found to be good and that under selective catalytic reduction (SCR) conditions was good as well [8,21-33]. These reports demonstrate that catalyst activity mainly depends on the preparation methods, heat treatment, oxidation state, location of the cations (tetrahedral or octahedral sites), and the presence of promoters. $\mathrm{MgCo}_{2} \mathrm{O}_{4}$ showed the best performance among a series of transition metal spinels (cobaltites, chromites, and ferrites) during $\mathrm{N}_{2} \mathrm{O}$ decomposition in the absence and presence of oxygen [21]. Earlier published work for the interaction of $\mathrm{CO}$ with $\mathrm{N}_{2} \mathrm{O}$ over $\mathrm{MCo}_{2} \mathrm{O}_{4}(\mathrm{M}=$ $\mathrm{Cu}, \mathrm{Co}, \mathrm{Ni}$ ) catalysts revealed that the activity is affected by the degree of $\mathrm{Co}^{2+}$ substitution as well as the degree of spinel inversion [22]. Yan et al. [23,24] investigated $\mathrm{N}_{2} \mathrm{O}$ decomposition over a series of $\mathrm{M}_{x} \mathrm{Co}_{1-x} \mathrm{Co}_{2} \mathrm{O}_{4}(\mathrm{M}=\mathrm{Mg}, \mathrm{Ni}$, $\mathrm{Zn}, x=0.0-0.99)$ spinel catalysts that they prepared by co-precipitation. Their results revealed that the catalytic activity depended on the degree of $\mathrm{Co}^{2+}$ substitution by $\mathrm{Mg}^{2+}, \mathrm{Ni}^{2+}$, or $\mathrm{Zn}^{2+}$. The highest activities were observed for the $\mathrm{Mg}_{0.54} \mathrm{Co}_{0.46} \mathrm{Co}_{2} \mathrm{O}_{4}, \mathrm{Ni}_{0.74} \mathrm{Co}_{0.26} \mathrm{Co}_{2} \mathrm{O}_{4}$, and $\mathrm{Zn}_{0.36} \mathrm{Co}_{0.64}{ }^{-}$ $\mathrm{Co}_{2} \mathrm{O}_{4}$ compositions.

Received 26 September 2010. Accepted 8 November 2010.

*Corresponding author. Tel: +2-088-2412429; Fax:+2-088-2342708; E-mail: babuzied@aun.edu.eg, babuzied@yahoo.com

Foundation item: Supported by Assiut University.

English edition available online at ScienceDirect (http://www.sciencedirect.com/science/journal/18722067). 
More recent literature reports about the promotion of $\mathrm{N}_{2} \mathrm{O}$ decomposition over $\mathrm{Co}_{3} \mathrm{O}_{4}$ spinel oxide revealed other particularly important contributions. Xue et al. [25] found that ceria-doped $\mathrm{Co}_{3} \mathrm{O}_{4}$ spinel oxide had a beneficial effect. Complete $\mathrm{N}_{2} \mathrm{O}$ conversion below $400{ }^{\circ} \mathrm{C}$ was observed for the catalyst with a $\mathrm{Ce} / \mathrm{Co}$ molar ratio of 0.05 . These authors suggest that $\mathrm{CeO}_{2}$ promotes the reduction of $\mathrm{Co}^{3+}$ to $\mathrm{Co}^{2+}$ by facilitating the desorption of adsorbed oxygen species, which is the rate-determining step for $\mathrm{N}_{2} \mathrm{O}$ decomposition. The same research group reported further activity enhancement for their $\mathrm{Co}_{3} \mathrm{O}_{4}-\mathrm{CeO}_{2}(\mathrm{Ce} / \mathrm{Co}=0.05)$ catalyst and this was due to the presence of residual $\mathrm{K}$ ions [26]. The role of alkali metal cations in the improvement of $\mathrm{N}_{2} \mathrm{O}$ decomposition by $\mathrm{Co}_{3} \mathrm{O}_{4}$ spinel oxide catalysts has been reported by many authors [8,27-29]. Potassium and cesium are superior to lithium and sodium in enhancing the $\mathrm{N}_{2} \mathrm{O}$ decomposition activity [27] whereas the optimum $\mathrm{M} / \mathrm{Co}$ doping level is $0.01-0.02$ and $0.05-0.1$ for potassium and cesium, respectively $[28,29]$. On the other hand, doping with alkaline earth cations has also been reported to promote $\mathrm{N}_{2} \mathrm{O}$ decomposition over $\mathrm{Co}_{3} \mathrm{O}_{4}$ whereas strontium and barium-doped catalysts show the highest activity $[8,33]$.

As an extension of this interesting literature data our investigation represents a systematic study for the preparation, characterization, and comparison of the direct $\mathrm{N}_{2} \mathrm{O}$ decomposition activity of a group of magnesium cobaltite catalysts with a general formula of $\mathrm{Mg}_{x} \mathrm{Co}_{1-x} \mathrm{Co}_{2} \mathrm{O}_{4}(0.0 \leq x \leq 1.0)$. For the most active catalyst, $\mathrm{MgCo}_{2} \mathrm{O}_{4}$, the effect of alkali element ( $\mathrm{Li}, \mathrm{Na}, \mathrm{K}$ and $\mathrm{Cs}$ ) doping on the increase in catalytic activity is also reported.

\section{Experimental}

\subsection{Catalyst preparation}

$\mathrm{Mg}_{x} \mathrm{Co}_{1-x} \mathrm{Co}_{2} \mathrm{O}_{4}(0.0 \leq x \leq 1.0)$ catalysts were prepared by aqueous solution impregnation. For each parent mixture, the required amounts of cobalt acetate and magnesium hydroxide were weighed to the nearest milligram. A solution of cobalt acetate was added to the magnesium hydroxide with constant stirring. The obtained mixtures were dried at $90{ }^{\circ} \mathrm{C}$ overnight. Finally, based on the thermal analysis results (vide infra), the parent mixtures were calcined in air at 500 ${ }^{\circ} \mathrm{C}$ for $3 \mathrm{~h}$ and then cooled to room temperature.

Pure $\mathrm{Co}_{3} \mathrm{O}_{4}$, i.e. $x=0.0$, was prepared by the calcination of cobalt acetate at $500{ }^{\circ} \mathrm{C}$ for $3 \mathrm{~h}$. Alkali-doped catalysts were prepared by the incipient wetness impregnation of $\mathrm{MgCo}_{2} \mathrm{O}_{4}$ with alkali carbonates $\left(\mathrm{Li}_{2} \mathrm{CO}_{3}, \mathrm{Na}_{2} \mathrm{CO}_{3}, \mathrm{~K}_{2} \mathrm{CO}_{3}\right.$, and $\mathrm{Cs}_{2} \mathrm{CO}_{3}$ ). The alkali metal/cobalt ratio was adjusted to 0.05 . The obtained mixtures were dried at $90{ }^{\circ} \mathrm{C}$ overnight and then calcined at $500{ }^{\circ} \mathrm{C}$ for $3 \mathrm{~h}$ in a static air atmosphere.

\subsection{Catalyst characterization}

Simultaneous thermogravimetric analysis (TGA) and differential thermal analysis (DTA) curves were recorded using a Shimadzu DT-60 apparatus at a heating rate of $10{ }^{\circ} \mathrm{C} / \mathrm{min}$ in air. X-ray diffraction (XRD) patterns of the calcined samples were recorded with a Philips diffractometer (type PW 103/00) using $\mathrm{Cu} K_{\alpha}$ radiation at room temperature and the other instrumental settings were $35 \mathrm{kV}$ and $20 \mathrm{~mA}$. Scanning electron micrographs were obtained using a JEOL JSM-5400 LV scanning electron microscope (SEM). Adsorption-desorption isotherms of nitrogen (at $-196{ }^{\circ} \mathrm{C}$ ) were obtained using a Quantachrome (Nova 3200 series) multi-gas adsorption apparatus. Specific surface areas were calculated from these isotherms by applying the BET equation. $S_{t}$ values were calculated using the $V_{a-t}$ plots of de Bore and the corresponding pore size distribution curves were constructed using the BJH method [34].

\subsection{Activity measurements}

Nitrous oxide decomposition was carried out in an electrically heated quartz tube reactor. The temperature in the reactor was measured using a thermocouple adjacent to the catalyst bed. Before each experiment $0.5 \mathrm{~g}$ of the catalyst was treated in $\mathrm{N}_{2}$ at $500{ }^{\circ} \mathrm{C}$ for $1 \mathrm{~h}$. The desired concentration of $\mathrm{N}_{2} \mathrm{O}$ was added with the aid of thermal mass flow controllers (AALBORG, DFC2600) using $\mathrm{N}_{2}$ as the balance gas. The volume flow rate was $200 \mathrm{~cm}^{3} / \mathrm{min}$ (NTP). In all experiments, the $\mathrm{N}_{2} \mathrm{O}$ reactor inlet concentration was 500 ppm. Quantitative analyses of the reactor's inlet and outlet gases were carried out using a magnetic oxygen analyzer (ABB, AO2020-Magnos 106) and a non-dispersive infrared analyzer for $\mathrm{N}_{2} \mathrm{O}$ and $\mathrm{NO}$ (ABB, AO2020-Uras 14). Preliminary experiments for the decomposition of nitrous oxide over all the catalysts showed the absence of NO in the exit gas. Nitrous oxide conversion was calculated using the formula $\left[\mathrm{N}_{2} \mathrm{O}\right]_{\text {conv. }}=\left(\left[\mathrm{N}_{2} \mathrm{O}\right]_{\text {in }}-\left[\mathrm{N}_{2} \mathrm{O}\right]_{\text {out }}\right) /\left[\mathrm{N}_{2} \mathrm{O}\right]_{\text {in }}$.

\section{Results and discussion}

\subsection{Catalyst characterization}

\subsubsection{TGA and DTA analyses}

The TGA and DTA thermograms obtained for the $\mathrm{MgCo}_{2} \mathrm{O}_{4}$ parent mixture are shown in Fig. 1. Several weight loss processes were observed upon heating the mixture to $1000{ }^{\circ} \mathrm{C}$. From ambient until around $200{ }^{\circ} \mathrm{C}$ three consecutive steps are present at around 79,114 , and $153{ }^{\circ} \mathrm{C}$ (DTG). These thermal events are endothermic in nature (Fig. 1(b)). These early weight loss steps are attributed to the 


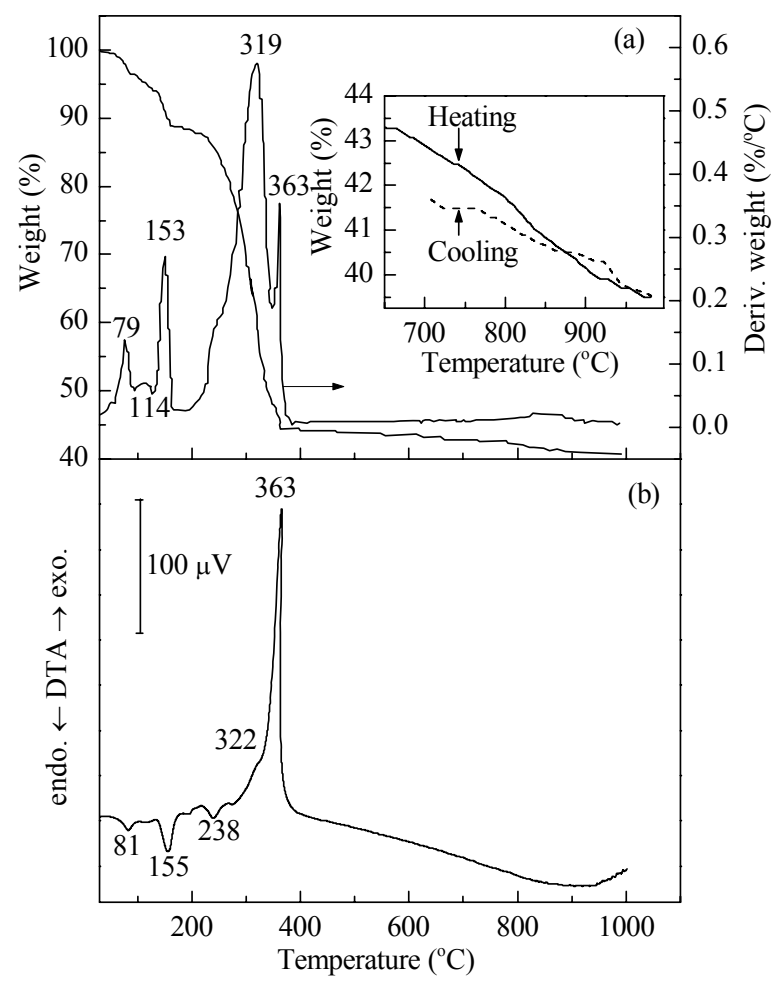

Fig. 1. TGA (a) and DTA (b) thermograms obtained by heating the $\mathrm{MgCO}_{2} \mathrm{O}_{4}$ parent in $\operatorname{air}\left(10^{\circ} \mathrm{C} / \mathrm{min}\right)$.

dehydration of cobalt acetate $[35,36]$. Heating the parent up to $400{ }^{\circ} \mathrm{C}$ is accompanied by a complex series of overlapping decomposition processes. It has been reported that the decomposition of anhydrous cobalt acetate takes place at 200-400 ${ }^{\circ} \mathrm{C}$ by the formation of three intermediates (hydroxy-acetate, oxy-acetate, and carbonate) eventually leading to the formation of $\mathrm{Co}_{3} \mathrm{O}_{4}$ (in air), $\mathrm{CoO}$ (in $\mathrm{N}_{2}$ ), and $\mathrm{Co}$ (in $\mathrm{H}_{2}$ ) $[35,36]$.

In addition, it has been reported that magnesium hydroxide decomposes to magnesium oxide at around $365{ }^{\circ} \mathrm{C}$ [37]. Therefore, it is plausible to relate the observed weight loss processes at $200-400{ }^{\circ} \mathrm{C}$ to the decomposition of anhydrous cobalt acetate and of magnesium hydroxide. Within the same temperature range the DTA thermogram contains a sharp exothermic peak with a maximum at $363{ }^{\circ} \mathrm{C}$. Two interesting points could be raised for this. First, upon heating a physical mixture of $\mathrm{Mg}(\mathrm{OH})_{2}$ and $\mathrm{Co}_{3} \mathrm{O}_{4}$ from ambient to $700{ }^{\circ} \mathrm{C}$ the obtained DTA thermogram (Fig. 2) has two endothermic peaks at 99 and $352^{\circ} \mathrm{C}$. The first one could be related to the removal of adsorbed water whereas the second one may be the decomposition of $\mathrm{Mg}(\mathrm{OH})_{2}$ and the solid state interaction between magnesium and cobalt oxides. Second, the reported work for the decomposition of anhydrous cobalt acetate indicates that this salt decomposes endothermically and exothermically in nitrogen and air atmospheres, respectively [35].

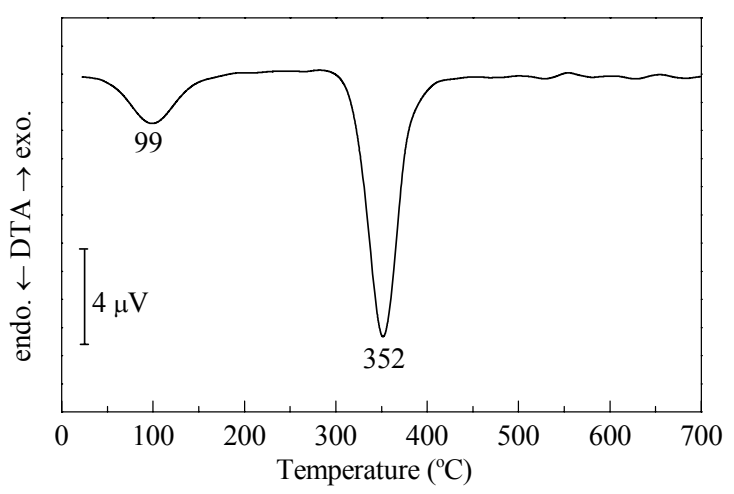

Fig. 2. DTA thermogram obtained by heating a physical mixture of $\mathrm{Mg}(\mathrm{OH})_{2}$ and $\mathrm{Co}_{3} \mathrm{O}_{4}$ in $\operatorname{air}\left(10^{\circ} \mathrm{C} / \mathrm{min}\right)$.

Therefore, it is plausible to relate the sharp exothermic peak at $363{ }^{\circ} \mathrm{C}$ (Fig. 1(a)) to the superposition of: (i) the combustion of the evolved gases accompanying the decomposition of cobalt acetate (exothermic), (ii) the decomposition of magnesium hydroxide as well as the solid state reaction between magnesium and cobalt oxides (endothermic). The final weight loss step in Fig. 1(a), which covers a wide temperature range from $600-950{ }^{\circ} \mathrm{C}$ can be attributed to the decomposition of magnesium cobaltite according to:

$$
\mathrm{MgCo}_{2} \mathrm{O}_{4} \rightarrow \mathrm{MgO}+2 \mathrm{CoO}+1 / 2 \mathrm{O}_{2}
$$

In other words, this step is related to the thermal reduction of $\mathrm{Co}^{3+}$ to $\mathrm{Co}^{2+}$. A similar observation was reported for $\mathrm{Co}_{3} \mathrm{O}_{4}$ and $\mathrm{Cu}_{x} \mathrm{Co}_{3-x} \mathrm{O}_{4}$ [38]. The DTA thermogram (Fig. 1(b)) shows that this thermal event is endothermic in nature. Interestingly, the cooling curve (Fig. 1(a)) reveals that this step is reversible. Therefore, the observed weight gain upon cooling could plausibly be explained by the following reaction:

$$
3 \mathrm{CoO}+1 / 2 \mathrm{O}_{2} \rightarrow \mathrm{Co}_{3} \mathrm{O}_{4}
$$

This is confirmed by an XRD analysis of the two samples that were calcined at 750 and $1000{ }^{\circ} \mathrm{C}$ (not shown), which indicates the coexistence of only $\mathrm{MgO}$ and $\mathrm{Co}_{3} \mathrm{O}_{4}$ phases in the obtained diffractograms.

\subsubsection{XRD analysis}

Based on the thermal analysis, different $\mathrm{Mg}_{x} \mathrm{Co}_{1-x} \mathrm{Co}_{2} \mathrm{O}_{4}$ catalysts were prepared by calcination for $3 \mathrm{~h}$ in static air at $500{ }^{\circ} \mathrm{C}$ and these compositions depended on their corresponding parent mixtures. Figure 3 shows XRD patterns of the obtained catalysts. Based on the diffraction peaks present all the catalysts had a good crystalline cobalt spinel structure (JCPDS 78-1970) and no other phases were detected. This suggests that $\mathrm{Mg}^{2+}$ ions replaced the $\mathrm{Co}^{2+}$ ions in the cobalt oxide spinel, $\mathrm{Co}_{3} \mathrm{O}_{4}$, giving corresponding $\mathrm{Mg}_{x} \mathrm{Co}_{1-x} \mathrm{Co}_{2} \mathrm{O}_{4}$ spinel oxides. The crystallite sizes of the different catalysts were calculated using the Scherrer equa- 


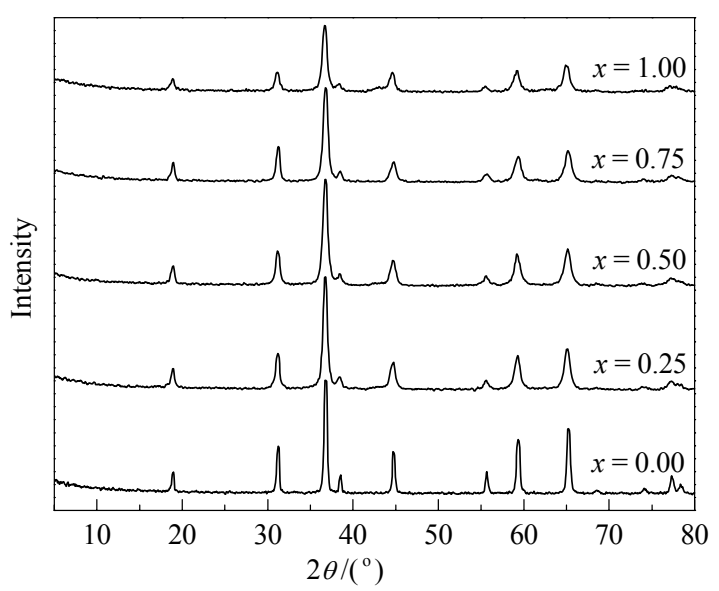

Fig. 3. XRD patterns of the $\mathrm{Mg}_{x} \mathrm{Co}_{1-x} \mathrm{Co}_{2} \mathrm{O}_{4}$ catalysts calcined at 500 ${ }^{\circ} \mathrm{C}$.

tion [4]. The calculated values are listed in the Table 1. It is evident that the magnesium containing spinels have smaller crystallite sizes than the $\mathrm{Co}_{3} \mathrm{O}_{4}$ spinel oxide. Additionally, an increase in the magnesium content of the catalyst is accompanied by a continuous decrease in the crystallite size.

\subsection{Catalytic activity measurements}

\subsection{1 $\mathrm{N}_{2} \mathrm{O}$ decomposition over the $\mathrm{Mg}_{x} \mathrm{Co}_{1-x} \mathrm{Co}_{2} \mathrm{O}_{4}$ catalysts}

Figure 4 shows the dependence of the steady-state conversion of $\mathrm{N}_{2} \mathrm{O}$ on the reactor temperature for the $\mathrm{Mg}_{x} \mathrm{Co}_{1-x} \mathrm{Co}_{2} \mathrm{O}_{4}$ catalysts calcined at $500{ }^{\circ} \mathrm{C}$. This figure reveals that the reaction over $\mathrm{Co}_{3} \mathrm{O}_{4}$ starts at $250{ }^{\circ} \mathrm{C}$ and this becomes lower for the magnesium containing catalysts.

The temperature dependence of the $\mathrm{N}_{2} \mathrm{O}$ conversion is the same for all the catalysts. Furthermore, increasing the $x$ value leads to a continuous increase in the $\mathrm{N}_{2} \mathrm{O}$ conversion and a maximum value of $67 \%$ was obtained over $\mathrm{MgCo}_{2} \mathrm{O}_{4}$ at $500{ }^{\circ} \mathrm{C}$. Two points could be raised in this respect. (i) The trend of activity variation with the $x$ value is different as reported by Yan et al. [23] who studied $\mathrm{N}_{2} \mathrm{O}$ decomposition over a series of $\mathrm{Mg}_{x} \mathrm{Co}_{1-x} \mathrm{Co}_{2} \mathrm{O}_{4}$ catalysts. They prepared the catalysts by co-precipitation using $\mathrm{K}_{2} \mathrm{CO}_{3}$ and observed the highest activity for the catalyst with an $x$ value of 0.54 . (ii) Our obtained conversion values are lower than those re-

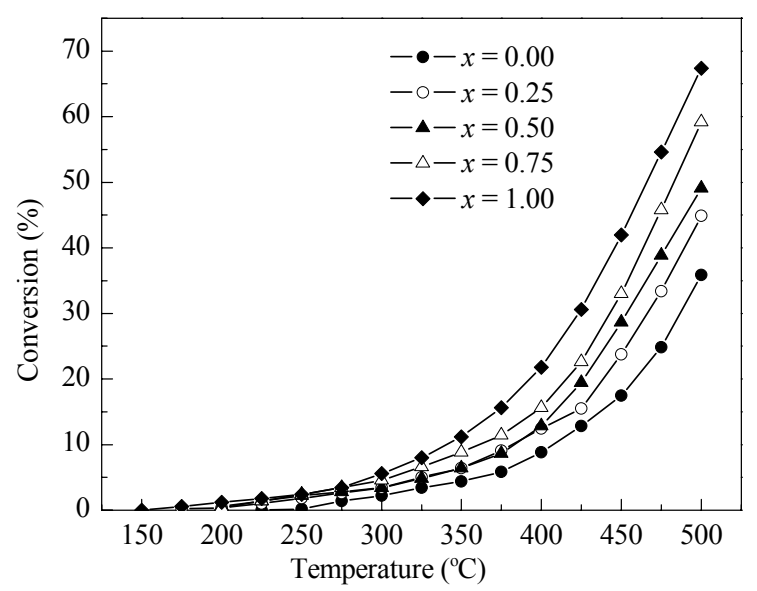

Fig. 4. Dependence of $\mathrm{N}_{2} \mathrm{O}$ conversion on the reactor temperatures for the $\mathrm{Mg}_{x} \mathrm{Co}_{1-x} \mathrm{Co}_{2} \mathrm{O}_{4}$ catalysts calcined at $500{ }^{\circ} \mathrm{C}$.

ported by this research group [23]. This catalytic activity difference can be attributed to the difference in the preparation method used or to the calcination conditions (vide infra).

The mechanism of the reaction between $\mathrm{N}_{2} \mathrm{O}$ and the catalysts active centers is generally thought to be a charge donation from the catalyst to the antibonding orbitals of $\mathrm{N}_{2} \mathrm{O}$, which destabilizes the $\mathrm{N}-\mathrm{O}$ bond and this leads to scission [3,39]. Therefore, electron charge transfer from the metal ion to the $\mathrm{N}_{2} \mathrm{O}$ molecule is a crucial step for $\mathrm{N}_{2} \mathrm{O}$ decomposition $[33,39]$. Electron transfer occurs from a low oxidation state metal cation, which then increases its oxidation state. The recoverability of the ion from a high to a low oxidation state is also important for the regeneration of the active centers. Accordingly, the activity of the $\mathrm{Co}_{3} \mathrm{O}_{4}$ oxide spinel $(x=0.0)$ is attributed to the coexistence of a $\mathrm{Co}^{2+}-\mathrm{Co}^{3+}$ ion pair because of a facile one electron transfer between these ions during $\mathrm{N}_{2} \mathrm{O}$ decomposition, as shown in the following mechanism [33]:

$$
\begin{aligned}
& \mathrm{N}_{2} \mathrm{O}_{(\mathrm{g})}+\mathrm{Co}^{2+} \rightarrow \mathrm{N}_{2} \mathrm{O}^{-} \text {(ads.) } \cdots \cdot \mathrm{Co}^{3+} \\
& \mathrm{N}_{2} \mathrm{O}^{-} \text {(ads.) }{ }^{\cdots} \cdot \mathrm{Co}^{3+} \rightarrow \mathrm{N}_{2(\mathrm{~g})}+\mathrm{O}^{-}{ }_{\text {(ads.) }} \cdot \mathrm{Co}^{3+} \\
& \mathrm{O}^{-}{ }_{\text {(ads.) }} \cdot \cdots \cdot \mathrm{Co}^{3+} \rightarrow 1 / 2 \mathrm{O}_{2(\mathrm{~g})}+\mathrm{Co}^{2+}
\end{aligned}
$$

Dell et al. [40] correlated the $\mathrm{N}_{2} \mathrm{O}$ decomposition activity of a series of metallic oxides with their semi-conductivity behavior. Based on their classification, the highest activity was observed over $p$-type semi-conductors whereas the

\begin{tabular}{|c|c|c|c|c|c|c|}
\hline$x$ value & $\begin{array}{l}\text { Crystallite } \\
\text { size (nm) }\end{array}$ & $\begin{array}{c}\text { TOF at } 500^{\circ} \mathrm{C} \\
\left(10^{-9} \mathrm{~mol} /\left(\mathrm{s} \cdot \mathrm{m}^{2}\right)\right)\end{array}$ & $A_{\mathrm{BET}} /\left(\mathrm{m}^{2} / \mathrm{g}\right)$ & $\begin{array}{c}\text { External surface area } \\
\left(\mathrm{m}^{2} / \mathrm{g}\right)\end{array}$ & $V_{\mathrm{p}} /\left(10^{-2} \mathrm{ml} / \mathrm{g}\right)$ & $\begin{array}{l}\text { Average pore } \\
\text { diameter }(\mathrm{nm}) \\
\end{array}$ \\
\hline 0.00 & 24.3 & 23.3 & 2 & 2 & 0.3 & 6.0 \\
\hline 0.25 & 16.6 & 24.3 & 3 & 4 & 0.6 & 9.8 \\
\hline 0.50 & 15.1 & 11.7 & 6 & 7 & 1.7 & 11.9 \\
\hline 0.75 & 14.7 & 9.6 & 8 & 8 & 2.6 & 12.6 \\
\hline 1.00 & 10.2 & 6.5 & 17 & 17 & 5.8 & 13.6 \\
\hline
\end{tabular}
lowest activity was correlated with $n$-type semi-conductivity.

Table 1 Crystallite size, TOF values, and textural data for the $\mathrm{Mg}_{x} \mathrm{Co}_{1-x} \mathrm{Co}_{2} \mathrm{O}_{4}$ catalysts 
Because $\mathrm{Co}_{3} \mathrm{O}_{4}$ is a $p$-type semi-conductor [33], this could be another reason for its $\mathrm{N}_{2} \mathrm{O}$ decomposition activity.

The calculated TOF values during $\mathrm{N}_{2} \mathrm{O}$ decomposition at $500{ }^{\circ} \mathrm{C}$ over the $\mathrm{Mg}_{x} \mathrm{Co}_{1-x} \mathrm{Co}_{2} \mathrm{O}_{4}$ catalysts are listed in the Table 1. The TOF is defined as the number of moles of $\mathrm{N}_{2} \mathrm{O}$ per second per square meter of the catalyst. From the combination of the data presented in Fig. 4 and Table 1 the activity is shown to be directly proportional to the $x$ value, i.e. the $\mathrm{Mg}$ content, on a weight basis. On the other hand it is inversely proportional based on the surface area. Xue et al. $[25,26]$ investigated $\mathrm{CeO}_{2}$ promoted $\mathrm{Co}_{3} \mathrm{O}_{4}$ using various $\mathrm{Ce} / \mathrm{Co}$ ratios during $\mathrm{N}_{2} \mathrm{O}$ decomposition. They pointed out that the increase in surface area is a very important factor in the high catalytic activity of these catalysts. The work of Chellam et al. [30] revealed that the partial substitution of $\mathrm{Co}^{2+}$ with $\mathrm{Mg}^{2+}$ increases the $\mathrm{N}_{2} \mathrm{O}$ decomposition activity on a weight basis over the $\mathrm{Mg}_{x} \mathrm{Co}_{1-x} \mathrm{Co}_{2} \mathrm{O}_{4}$ catalysts. On a surface area basis the catalysts containing more Co were more active. Yan et al. [23] reported that these catalysts, where $\mathrm{Co}^{2+}$ was partially substituted with $\mathrm{Mg}^{2+}$, were more active than pure $\mathrm{Co}_{3} \mathrm{O}_{4}$ during $\mathrm{N}_{2} \mathrm{O}$ decomposition and this was independent of catalyst weight or surface area. Therefore, the results presented here are in line with those of Chellam's group [30]. It seems that increasing the mole ratio of $\mathrm{Mg} / \mathrm{Co}$ is important in ensuring a large surface area but Co is the more active species in determining the ultimate catalytic activity.

The role of alkaline earth cations in enhancing the $\mathrm{N}_{2} \mathrm{O}$ decomposition over $\mathrm{Co}_{3} \mathrm{O}_{4}$ has been reported in the literature. Ohnishi et al. [8] reported an electronic promotion effect for the Ca-, Sr-, and $\mathrm{Ba}$-doped $\mathrm{Co}_{3} \mathrm{O}_{4}$ catalysts during $\mathrm{N}_{2} \mathrm{O}$ decomposition. More recently, an electronic interaction between cobalt and strontium or barium cations has been suggested over $\mathrm{SrCO}_{3}-$ and $\mathrm{BaCO}_{3}-\mathrm{Co}_{3} \mathrm{O}_{4}$ catalysts [33]. This interaction produces electron-rich cobalt species having a higher electron donation ability toward $\mathrm{N}_{2} \mathrm{O}$ molecules, which activates $\mathrm{N}_{2} \mathrm{O}$ adsorption leading to its decomposition. It has also been reported that the presence of $\mathrm{Mg}^{2+}$ helps $\mathrm{N}_{2} \mathrm{O}$ adsorption over $\mathrm{Mg}_{x} \mathrm{Co}_{1-x} \mathrm{Co}_{2} \mathrm{O}_{4}$ catalysts, which facilitates electron transfer from $\mathrm{Co}^{2+}[30]$. Figure 5 shows the DTA thermograms obtained by heating the $500{ }^{\circ} \mathrm{C}$ calcined $\mathrm{Mg}_{x} \mathrm{Co}_{1-x} \mathrm{Co}_{2} \mathrm{O}_{4}$ catalysts that have $x$-values of $0.00-1.00$ in air to $1000{ }^{\circ} \mathrm{C}$. For $\mathrm{Co}_{3} \mathrm{O}_{4}$, one sharp endothermic peak is present at $915{ }^{\circ} \mathrm{C}$. This peak is attributed to the thermal reduction of $\mathrm{Co}^{3+}$ to $\mathrm{Co}^{2+}$. The introduction of increased amounts of $\mathrm{Mg}^{2+}$, i.e., increasing the $x$-value leads to a continuous shift of this peak toward lower temperatures. For $\mathrm{MgCo}_{2} \mathrm{O}_{4}$ the maximum of this peak is at about $815{ }^{\circ} \mathrm{C}$. This peak becomes broader with an increase in the $x$-value, i.e., it covers a wider range of temperatures. It has been reported that the role of alkali cations in the increase of $\mathrm{N}_{2} \mathrm{O}$ decomposition activity is to enhance the $\mathrm{Co}^{3+} \rightarrow \mathrm{Co}^{2+}$ re-

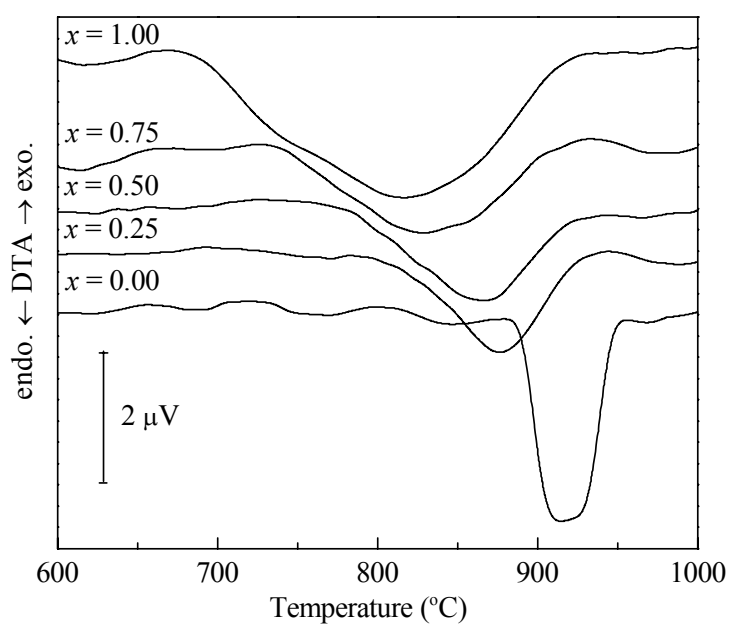

Fig. 5. DTA thermograms obtained by heating the $\mathrm{Mg}_{x} \mathrm{Co}_{1-x} \mathrm{Co}_{2} \mathrm{O}_{4}$ catalysts that were calcined at $500^{\circ} \mathrm{C}$ in air $\left(10^{\circ} \mathrm{C} / \mathrm{min}\right)$.

duction for the cobalt based catalysts, i.e., the regeneration of $\mathrm{Co}^{2+}$ ions that are required for $\mathrm{N}_{2} \mathrm{O}$ adsorption and subsequent decomposition $[26,42]$. Based on the data shown in Fig. 5, it is plausible that the role of the added $\mathrm{Mg}^{2+}$ ions is to enhance the $\mathrm{Co}^{3+} \rightarrow \mathrm{Co}^{2+}$ reduction under catalytic conditions and thus increase the catalytic activity.

Regarding the influence of the catalyst's crystallite size, an inverse relationship has been reported for Ag crystallite size and $\mathrm{N}_{2} \mathrm{O}$ decomposition activity for a series of $\mathrm{Ag} / \mathrm{Al}_{x} \mathrm{Fe}_{2-x} \mathrm{O}_{3}$ catalysts [4]. It has been demonstrated that the highest $\mathrm{N}_{2} \mathrm{O}$ decomposition activity is obtained over catalysts that have a lower $\mathrm{Co}_{3} \mathrm{O}_{4}$ crystallite size for a series of $\mathrm{SrCO}_{3}$ - and $\mathrm{BaCO}_{3}-\mathrm{Co}_{3} \mathrm{O}_{4}$ catalysts [33]. Table 1 reveals that an increase in the $\mathrm{Mg}$ content is accompanied by a continuous decrease in catalyst crystallite size. Therefore, the increased activity of the magnesium-containing catalysts can be related to the observed decrease in their crystallite size.

An additional role of magnesium can be understood upon investigating the catalyst's texture. Nitrogen adsorptiondesorption isotherms for the $\mathrm{Mg}_{x} \mathrm{Co}_{1-x} \mathrm{Co}_{2} \mathrm{O}_{4}$ catalysts (not shown) were found to be type II according to IUPAC's classification, indicating a multilayer adsorption process [34]. The obtained hysteresis loops are nearly type H3. The obtained $A_{\mathrm{BET}}$ values (Table 1) show a continuous increase with magnesium content, i.e., with $x$-value. A similar observation has been reported for the $\mathrm{Mg}_{x} \mathrm{Co}_{1-x} \mathrm{Co}_{2} \mathrm{O}_{4}$ prepared by co-precipitation [30]. We believe that increasing the $x$-value and undertaking low-temperature calcination prevents the sample from recrystallization, which is important for an increase in the $A_{\mathrm{BET}}$ [30]. Table 1 also reveals that increasing the $A_{\mathrm{BET}}$ is accompanied by a continuous decrease in the spinel crystallite size, which is in agreement with the work reported for $\mathrm{Co}_{3} \mathrm{O}_{4} / \mathrm{CeO}_{2}$ [26]. 
Figure 6 shows that the pore size distribution curves of the $\mathrm{Mg}_{x} \mathrm{Co}_{1-x} \mathrm{Co}_{2} \mathrm{O}_{4}$ catalysts are different, as calculated by the $\mathrm{BJH}$ method. In addition, the adsorption parameters are listed in Table 1. Figure 6 reveals that the introduction of magnesium into $\mathrm{Co}_{3} \mathrm{O}_{4}$ is accompanied by a dramatic textural change. For the catalysts with $x=0.5$ and 0.75 , mesoporosity develops as indicated by the presence of the peak at nearly the same pore diameter in the mesoporous region. With a further increase in the magnesium content another peak emerged in the vicinity of the microporous region. The calculated total pore volume and average pore diameter values increase with an increase in the magnesium content (Table 1). Having the same pore diameter indicates that increasing the $A_{\mathrm{BET}}$ values (Table 1), as a result of increasing the magnesium content, results in an increase in the number of pores already present that have nearly the same shape and the same dimensions in the mesoporous region. This is also illustrated by the fact that the height of the distribution curves increase upon increasing the magnesium content. The exploratory work of Pérez-Ramírez et al. [41] revealed the development of mesopores as a consequence of alkali treatment for Fe-ZSM-5. The development of mesopores largely improved accessibility and gas transport, which in turn improved the $\mathrm{N}_{2} \mathrm{O}$ decomposition activities of their catalysts [41]. Therefore, it is plausible to suggest that the improved activity of the magnesium containing catalysts could be related to improved accessibility as a consequence of mesopore development.

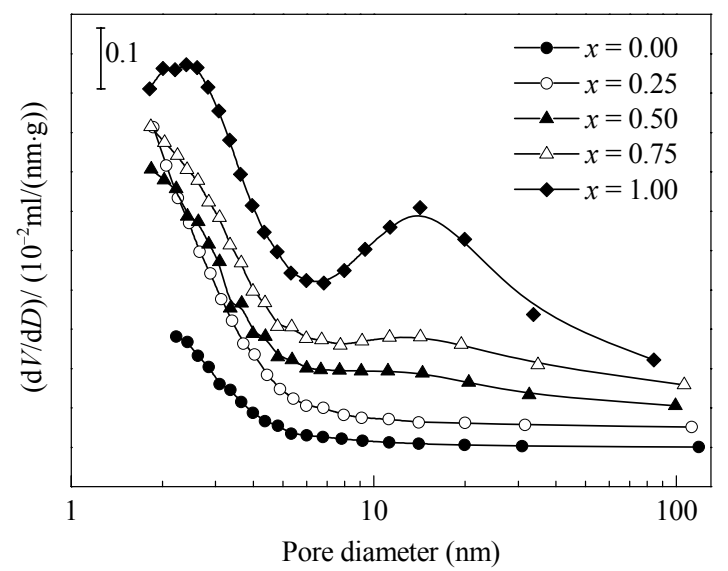

Fig. 6. Influence of increasing $x$-values on the porosity of the $\mathrm{Mg}_{x} \mathrm{Co}_{1-x} \mathrm{Co}_{2} \mathrm{O}_{4}$ catalysts.

\subsubsection{Influence of the alkali cation promoters}

Many reports exist about the influence of alkali cations in the promotion of $\mathrm{N}_{2} \mathrm{O}$ decomposition over various catalysts [8,26-29,42]. However, there is a lack of information about the role of these ions over magnesium cobaltite catalysts. Therefore, this study was extended to investigate the influ- ence of alkali modification in enhancing $\mathrm{N}_{2} \mathrm{O}$ decomposition over the most active catalyst of the $\mathrm{Mg}_{x} \mathrm{Co}_{1-x} \mathrm{Co}_{2} \mathrm{O}_{4}$ series, i.e., $\mathrm{MgCo}_{2} \mathrm{O}_{4}$. The obtained results are shown in Fig. 7 , in which the $\mathrm{N}_{2} \mathrm{O}$ decomposition is plotted as a function of temperature for the $\mathrm{MgCo}_{2} \mathrm{O}_{4}$ and alkali promoted $\mathrm{MgCo}_{2} \mathrm{O}_{4}$ catalysts. All the alkali promoted catalysts exhibit a higher $\mathrm{N}_{2} \mathrm{O}$ decomposition activity $\left(T_{50}\right.$ values of 405,374 , 308 , and $332{ }^{\circ} \mathrm{C}$ for the Li-, Na-, K-, and Cs-promoted catalysts, respectively) compared with that of the un-promoted $\mathrm{MgCo}_{2} \mathrm{O}_{4}\left(T_{50}=467{ }^{\circ} \mathrm{C}\right)$. In other words, the activity order is: un-promoted $<\mathrm{Li}<\mathrm{Na}<\mathrm{Cs}<\mathrm{K}$.

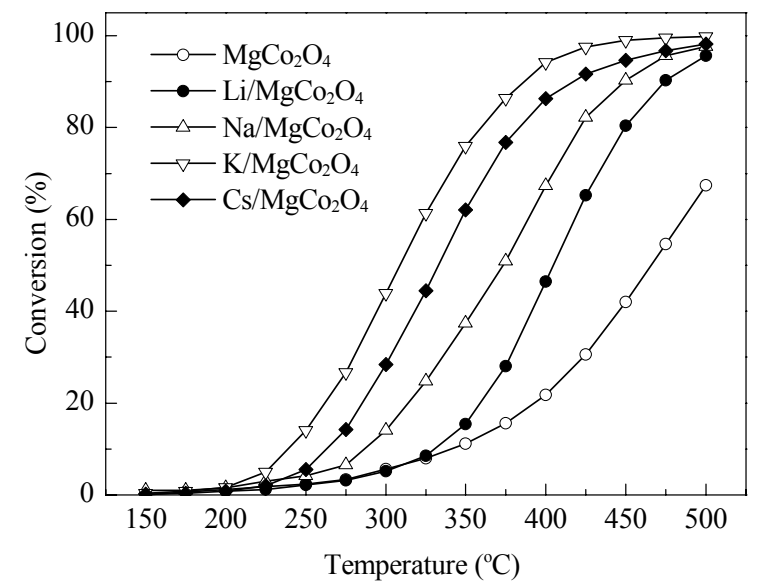

Fig. 7. Dependence of $\mathrm{N}_{2} \mathrm{O}$ conversion on the reactor temperature for $\mathrm{MgCo}_{2} \mathrm{O}_{4}$ and the alkali containing $\mathrm{MgCo}_{2} \mathrm{O}_{4}$ catalysts $(\mathrm{M} / \mathrm{Co}=0.05)$.

Stelmachowski et al. [27] reported the following activity order for alkali promoted $\mathrm{Co}_{3} \mathrm{O}_{4}$ catalysts: un-promoted $\sim \mathrm{Li}$ $<<\mathrm{Na}<\mathrm{K}<\mathrm{Cs}$. This contradicted the results reported by Ohnishi et al. [8] who showed that $\mathrm{Co}_{3} \mathrm{O}_{4}$ promoted by $\mathrm{Li}$ and $\mathrm{Na}$ exhibited higher $\mathrm{N}_{2} \mathrm{O}$ decomposition performance compared with $\mathrm{K}$ and $\mathrm{Cs}$ promoted catalysts. In our case it is obvious that the promotional effect of potassium was superior to that of the other cations. Accordingly, the influence of changing the $\mathrm{K} / \mathrm{Co}$ ratio was investigated.

Figure 8 shows the variation of $\mathrm{N}_{2} \mathrm{O}$ conversion with $\mathrm{K} / \mathrm{Co}$ ratio over the $\mathrm{K} / \mathrm{MgCo}_{2} \mathrm{O}_{4}$ catalysts from $250-500{ }^{\circ} \mathrm{C}$. Figure 8 reveals that over the whole temperature range, $\mathrm{K}$-doping even at a small ratio $(\mathrm{K} / \mathrm{Co}=0.0125)$ results in a noticeable increase in activity. A further increase in the $\mathrm{K} / \mathrm{Co}$ ratio is accompanied by a continuous increase in activity until $\mathrm{K} / \mathrm{Co}=0.05$. After this ratio a continuous decrease in activity is evident. However, all the K-doped catalysts had a higher activity compared with the un-doped $\mathrm{MgCo}_{2} \mathrm{O}_{4}$ catalyst. Considering the pronounced enhancement upon alkali doping, the reported extraordinarily high $\mathrm{N}_{2} \mathrm{O}$ decomposition activity over the $\mathrm{Mg}_{x} \mathrm{Co}_{1-x} \mathrm{Co}_{2} \mathrm{O}_{4}$ catalysts [23], compared with that shown in Fig. 4, can be related to the presence of residual potassium ions and these cannot be avoided in the co-precipitation procedure [26]. 


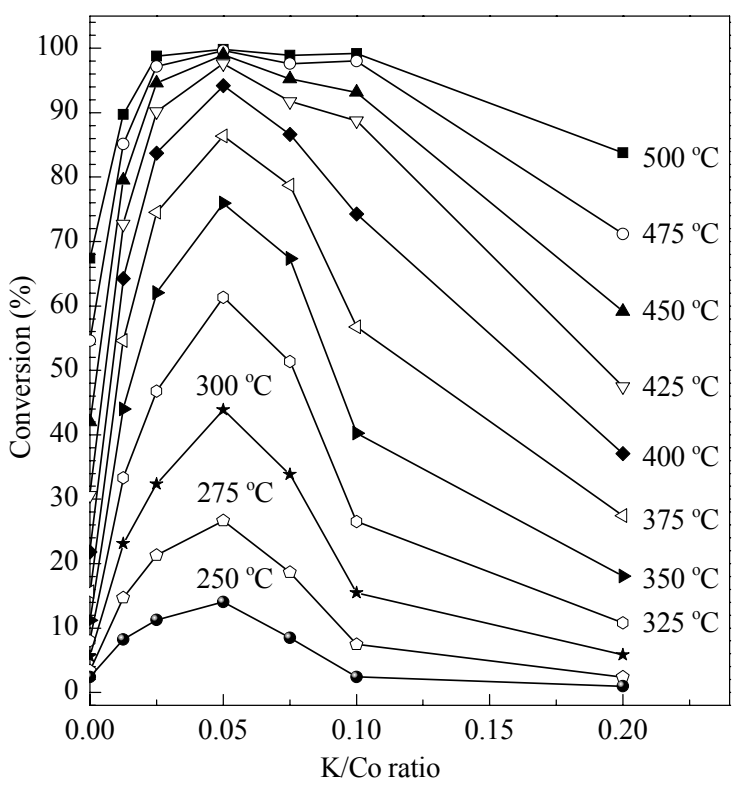

Fig. 8. Dependence of $\mathrm{N}_{2} \mathrm{O}$ conversion on the $\mathrm{K} / \mathrm{Co}$ ratio over $\mathrm{K} / \mathrm{MgCO}_{2} \mathrm{O}_{4}$ catalysts at different reactor temperatures.

The proposed redox mechanism of $\mathrm{N}_{2} \mathrm{O}$ decomposition (equations (3-5)) involves $\mathrm{N}_{2} \mathrm{O}$ adsorption on the catalyst active sites, which can be considered to be charge donation from the catalyst surface to $\mathrm{N}_{2} \mathrm{O}$. Adsorbed $\mathrm{N}_{2} \mathrm{O}$ decomposes into nitrogen and adsorbed oxygen. Oxygen desorption is believed to be the rate determining step. It is obvious that these steps are strongly dependent on the electronic properties of the catalyst's surface. Oxygen is one of the most electronegative elements and thus it forms polar bonds with other elements (with lower electronegativities). Oxygen and its partner atom in these bonds acquire negative and positive charges, respectively. It is known that alkali cations have the lowest electronegativity values among the elements of the periodic table. Therefore, when oxygen exists in the coordination sphere of one of these cations it acquires a more negative charge. In other words, and based on Sanderson's approach of the polarity of bonds they become highly basic. During $\mathrm{N}_{2} \mathrm{O}$ decomposition over the alkali promoted $\mathrm{Co}_{3} \mathrm{O}_{4}$ spinel, electron donation occurs from the highly basic oxygen anions surrounding the alkali cations to the cobalt ion and this increases the electron density of the cobalt ions, which plays a vital role in enhancing $\mathrm{N}_{2} \mathrm{O}$ activation [28,29]. Thermal analysis results of the $\mathrm{K}$ - and Cs-doped $\mathrm{MgCo}_{2} \mathrm{O}_{4}$ catalysts (not shown) revealed that both $\mathrm{K}$ and $\mathrm{Cs}$ shifts the spinel decomposition step, i.e. the $\mathrm{Co}^{3+}$ $\rightarrow \mathrm{Co}^{2+}$ reduction, towards lower temperatures compared with $\mathrm{MgCo}_{2} \mathrm{O}_{4}$. However, the observed shift is more pronounced for K- than for Cs-containing catalysts. Therefore, it is plausible to suggest that the enhancement effect of the added alkali cations during $\mathrm{N}_{2} \mathrm{O}$ decomposition over the $\mathrm{MgCo}_{2} \mathrm{O}_{4}$ catalyst is related to the enhanced redox proper- ties induced by these cations.

Cheng et al. [42], based on temperature-programmed reduction (TPR) results, stated that doping with excess potassium $(\mathrm{K} / \mathrm{Co}>0.08)$ clearly blocked active sites, which resulted in a decrease of the catalytic activity and this shows the dependence of $\mathrm{N}_{2} \mathrm{O}$ conversion on the $\mathrm{K}$ concentration. Pasha et al. [28] investigated cesium-promoted $\mathrm{Co}_{3} \mathrm{O}_{4}$ and related the observed decrease in activity for the catalysts with a $\mathrm{Cs} / \mathrm{Co}>0.05$ to the Hedvall effect [43]. During catalyst preparation the alkaline cations distribute on the surface and also in the bulk of the catalysts, which decreases their activities. An analysis of the reason for the observed activity decrease at high $\mathrm{K} / \mathrm{Co}$ ratios for the $\mathrm{K}$-promoted $\mathrm{MgCo}_{2} \mathrm{O}_{4}$ catalysts is of interest. Therefore, we carried out a texture analysis using SEM and $\mathrm{N}_{2}$ adsorption. Figure 9 shows the SEM micrographs of $\mathrm{MgCo}_{2} \mathrm{O}_{4}$ and its potassium-promoted catalysts $(\mathrm{K} / \mathrm{Co}=0.05$ and 0.2$)$. The morphology of the $\mathrm{MgCo}_{2} \mathrm{O}_{4}$ sample (Fig. 9(a)) consists of a network of: (i) spherical crystallites of $0.1-0.44 \mu \mathrm{m}$ in size and (ii) irregular holes distributed among the various particles without a characteristic size or shape. This morphology resembles that reported for $\mathrm{Co}_{3} \mathrm{O}_{4}$ [25]. The $\mathrm{K} / \mathrm{MgCo}_{2} \mathrm{O}_{4}(\mathrm{~K} / \mathrm{Co}=0.05)$ sample (Fig. 9(b)) possesses the same morphological fea-
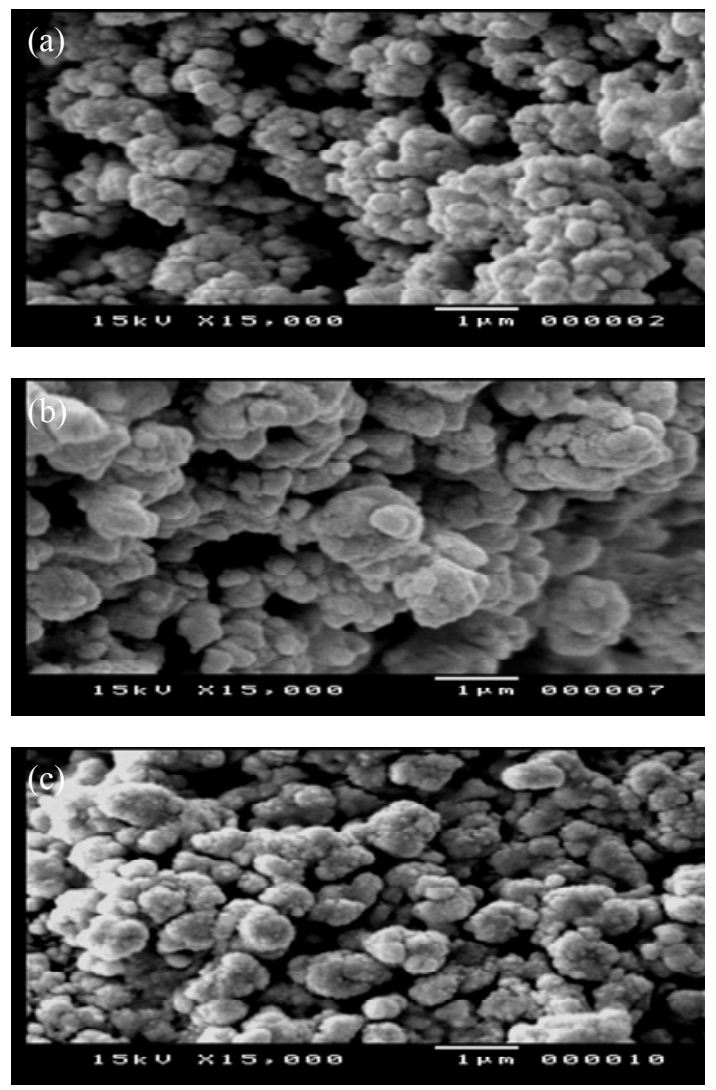

Fig. 9. $\mathrm{SEM}$ micrographs of $\mathrm{MgCo}_{2} \mathrm{O}_{4}$ (a) and its K-promoted catalysts with $\mathrm{K} / \mathrm{Co}=0.05$ (b) and $\mathrm{K} / \mathrm{Co}=0.2$ (c) after calcination at 500 ${ }^{\circ} \mathrm{C}$. 
tures as the $\mathrm{MgCo}_{2} \mathrm{O}_{4}$ sample but with larger grain sizes and smaller irregular holes. The micrograph of the $\mathrm{K} / \mathrm{MgCo}_{2} \mathrm{O}_{4}$ $(\mathrm{K} / \mathrm{Co}=0.2)$ sample (Fig. 9(c)) resembles that of the former catalyst. However, it has the smallest pores among the three catalysts. From the SEM it is plausible that the introduction of $\mathrm{K}$ into the $\mathrm{MgCo}_{2} \mathrm{O}_{4}$ catalyst enhances the densification and sintering processes. This suggestion is reinforced by the results of the $\mathrm{N}_{2}$ adsorption measurements.

Adsorption-desorption isotherms of nitrogen measured on the K-promoted $\mathrm{MgCo}_{2} \mathrm{O}_{4}$ catalysts (not shown) were found to be type II according to the IUPAC classification [34]. The corresponding textural data (not shown) reveals a noticeable gradual decrease in both $A_{\mathrm{BET}}$ and $V_{\mathrm{p}}$ as a result of increasing the $\mathrm{K} / \mathrm{Co}$ ratio. This may suggest that effective pore blocking accompanies the increase in $\mathrm{K}$ content. This is supported by the observation that the closure point of the hysteresis loop does not vary dramatically with an increase in the $\mathrm{K} / \mathrm{Co}$ ratio.

Pore blocking should lead to a considerable decrease in the total pore volume but not the pore diameter [44]. This implies that the pores that escape blocking should retain their original diameters. Therefore, the results indicate that an increase in the $\mathrm{K} / \mathrm{Co}$ ratio up to 0.075 is accompanied by a continuous decrease in the average pore diameter. The catalysts with a higher $\mathrm{K} / \mathrm{Co}$ ratio show a mild increase in average pore diameter. In addition to pore blocking the occurrence of pore narrowing may be inferred for an increase in the $\mathrm{K} / \mathrm{Co}$ ratio. The pore size distribution curves of $\mathrm{MgCo}_{2} \mathrm{O}_{4}$ and its $\mathrm{K}$ promoted catalysts (not shown) reveals that increasing the $\mathrm{K}$ content to $\mathrm{K} / \mathrm{Co}=0.05$ results in a decrease in the height of the peak that characterizes the mesopores, i.e. the peak at $13.8 \mathrm{~nm}$, together with a peak shift to higher values. At higher K/Co ratios, the peaks at $2.3 \mathrm{~nm}$ and higher pore diameters disappear. Therefore, increasing the $\mathrm{K}$ content in the catalyst results in the elimination of mesoporosity. From the data shown in Fig. 8 and based on the discussion in section 2.2.1 together with the information from the texture analysis, the observed activity decrease at $\mathrm{K} / \mathrm{Co}>0.05$ can be attributed to the loss of mesoporosity. In other words, two competing effects exist upon increasing the K/Co ratio: (i) an increase in the electron donation ability of the catalyst which enhances $\mathrm{N}_{2} \mathrm{O}$ activation and (ii) an elimination of mesoporosity, which leads to a decrease in catalyst activity. Therefore, the catalyst with a K/Co ratio of 0.05 shows the optimal balance between these two effects.

\section{Conclusions}

A structural analysis of a series of $\mathrm{Mg}_{x} \mathrm{Co}_{1-x} \mathrm{Co}_{2} \mathrm{O}_{4}(x=$ $0.0,0.25,0.50,0.75$, and 1.00) catalysts, that were prepared by the double decomposition of $\mathrm{Mg}(\mathrm{OH})_{2}$ and
$\mathrm{Co}\left(\mathrm{CH}_{3} \mathrm{COO}\right)_{2} \cdot 4 \mathrm{H}_{2} \mathrm{O}$ mixtures at $500{ }^{\circ} \mathrm{C}$, revealed that all the catalysts have a spinel structure. The $\mathrm{N}_{2} \mathrm{O}$ decomposition activity of the $\mathrm{Mg}_{x} \mathrm{Co}_{1-x} \mathrm{Co}_{2} \mathrm{O}_{4}$ catalysts is controlled by many parameters such as the magnesium content, crystallite size, surface area, and mesoporosity. A continuous increase in activity was obtained by increasing the Mg-content, which is accompanied by a decrease in the crystallite size, an increase in the surface area, and the development of mesopores. A marked increase in activity was obtained upon doping the $\mathrm{MgCo}_{2} \mathrm{O}_{4}$ with alkali cations ( $\mathrm{Li}, \mathrm{Na}, \mathrm{K}$, and $\mathrm{Cs}$ ). The activity order that we found is: un-promoted $<\mathrm{Li}<\mathrm{Na}$ $<$ Cs $<$ K-promoted catalyst. The increase in activity because of the added alkali cations is attributed to an induced electron interaction, which improves the electron donation ability of the cobalt ions and this facilitates $\mathrm{N}_{2} \mathrm{O}$ adsorption and decomposition. Changing the $\mathrm{K} / \mathrm{Co}$ ratio revealed that the maximum activity was obtained over the catalyst with a $\mathrm{K} / \mathrm{Co}$ of 0.05 . At higher $\mathrm{K} / \mathrm{Co}$ ratios, a continuous decrease in activity was observed. Considering the $\mathrm{N}_{2}$ adsorption and SEM results, a considerable amount of sintering and a loss of mesopores occurs when $\mathrm{K}_{2} \mathrm{CO}_{3}$ is added to $\mathrm{MgCo}_{2} \mathrm{O}_{4}$. The observed decrease in activity for the catalysts with $\mathrm{K} / \mathrm{Co}>0.05$ is related to the textural modification accompanying the increase in $\mathrm{K}_{2} \mathrm{CO}_{3}$.

\section{Acknowledgments}

The author would like to gratefully acknowledge the Deutscher Akademischer Austausch Dienst (DAAD) for granting us the use of gas analyzers for these experiments.

\section{References}

1 Centi G, Perathoner S, Vazzana F, Marella M, Tomaselli M, Mantegazza M. Adv Environ Res, 2000, 4: 325

2 http://unfccc.int/ghg_emissions_data/items/3800.php

3 Kapteijn F, Rodriguez-Mirasol J, Moulijn J A. Appl Catal B, 1996, 9: 25

4 Abu-Zied B M. Appl Catal A, 2008, 334: 234

5 Abu-Zied B M, Schwieger W, Unger A. Appl Catal B, 2008, 84: 277

6 Abu-Zied B M, Schwieger W. Appl Catal B, 2009, 85: 120

7 Melián-Cabrera I, Espinosa S, Groen J C, v/d Linden B, Kapteijn F, Moulijn J A. J Catal, 2006, 238: 250

8 Ohnishi C, Asano K, Iwamoto S, Chikama K, Inoue M. Catal Today, 2007, 120: 145

9 Pirngruber G D, Frunz L, Pieterse J A Z. J Catal, 2006, 243: 340

10 Sivasankar B N, Govindarajan S. Mater Res Bull, 1996, 31: 47

11 Sharma Y, Sharma N, Subba Rao G V, Chowdari B V R. Solid State Ionics, 2008, 179: 587

12 Schmidt-Szaøowski K, Krawczyk K, Petryk J. Appl Catal A, 1998, 175: 147 
13 El-Shobaky H G. Appl Catal A, 2004, 278: 1

14 Pollard M J, Weinstock B A, Bitterwolf T E, Griffiths P R, Newbery A P, Paine J B. J Catal, 2008, 254: 218

15 Manova E, Tsoncheva T, Estournès $\mathrm{Cl}$, Paneva $\mathrm{D}$, Tenchev $\mathrm{K}$, Mitov I, Petrov L. Appl Catal A, 2006, 300: 170

16 Ataloglou T, Fountzoula C, Bourikas K, Vakros J, Lycourghiotis A, Kordulis C. Appl Catal A, 2005, 288: 1

17 Mirzaei A A, Faizi M, Habibpour R. Appl Catal A, 2006, 306: 98

18 Liu Q, Wang L-C, Chen M, Cao Y, He H-Y, Fan K-N. J Catal, 2009, 263: 104

19 Li J, Liang X, Xu S, Hao J. Appl Catal B, 2009, 90: 307

20 Radwan N R E, El-Shobaky G A, Fahmy Y M. Appl Catal A, 2004, 274: 87

21 Russo N, Fino D, Saracco G, Specchia V. Catal Today, 2007, 119: 228

22 Sundararajan R, Srinivasan V. Appl Catal A, 1996, 141: 45

23 Yan L, Ren T, Wang X, Ji D, Suo J. Appl Catal B, 2003, 45: 85

24 Yan L, Ren T, Wang X, Gao Q, Ji D, Suo J. Catal Commun, 2003, 4: 505

25 Xue L, Zhang C, He H, Teraoka Y. Appl Catal B, 2007, 75: 167

26 Xue L, Zhang C, He H, Teraoka Y. Catal Today, 2007, 126: 449

27 Stelmachowski P, Maniak G, Kotarba A, Sojka Z. Catal Commun, 2009, 10: 1062

28 Pasha N, Lingaiah N, Seshu Babu N, Siva Sankar Reddy P, Sai
Prasad P S. Catal Commun, 2008, 10: 132

29 Asano K, Ohnishi C, Iwamoto S, Shioya Y, Inoue M. Appl Catal B, 2008, 78: 242

30 Chellam U, Xu Z P, Zeng H C. Chem Mater, 2000, 12: 650

31 Sundararajan R, Srinivasan V. Appl Catal, 1991, 73: 165

32 Shen Q, Li L, Li J, Tian H, Hao Z. J Hazard Mater, 2009, 163: 1332

33 Abu-Zied B M, Soliman S A. Catal Lett, 2009, 132: 299

34 Leofanti G, Padovan M, Tozzola G, Venturelli B. Catal Today, 1998, 41: 207

35 Mohamed M A, Halawy S A, Ebrahim M M. J Thermal Anal, 1994, 41: 387

36 Wanjun T, Donghua C. Chem Pap, 2007, 61: 329

37 Liptay G. Atlas of Thermoanalytical Curves, Vol. 3. London: Heyden \& Sons, 1974. 136

38 Shaheen W M, Ali A A. Mater Res Bull, 2001, 36:1703

39 Zeng H C, Lin J, Teo W K, Wu J C, Tan K L. J Mater Res, 1995, 10: 545

40 Dell R M, Stone F S, Tiley P F. Trans Faraday Soc, 1953, 49: 201

41 Pérez-Ramírez J, Kapteijn F, Groen J C, Doménech A, Mul G, Moulijn J A. J Catal, 2003, 214: 33

42 Cheng H, Huang Y, Wang A, Li L, Wang X, Zhang T. Appl Catal B, 2009, 89: 391

43 Hedvall J A. Adv Catal, 1956, 8: 1

44 Fouad N E, Knözinger H, Ismail H M, Zaki M I. Z Phys Chem, 1991, 173: 201 